University for Business and Technology in Kosovo

UBT Knowledge Center

Nov 2nd, 9:00 AM - Nov 3rd, 5:00 PM

\title{
Financial Analysis and Techniques to Forecast the possible Bankruptcy of Firms in Terms of Economic Crisis (The Case of Albania)
}

Antoneta Polo

Eqrem Cabej University, neta_polo@yahoo.com

Vjollca Karapici

University of Tirana, v_karapici@yahoo.com

Enkela Caca

Eqrem Cabej University, ebabaramo@yahoo.com

Follow this and additional works at: https://knowledgecenter.ubt-uni.net/conference

Part of the Business Commons

\section{Recommended Citation}

Polo, Antoneta; Karapici, Vjollca; and Caca, Enkela, "Financial Analysis and Techniques to Forecast the possible Bankruptcy of Firms in Terms of Economic Crisis (The Case of Albania)" (2012). UBT International Conference. 59.

https://knowledgecenter.ubt-uni.net/conference/2012/all-events/59

This Event is brought to you for free and open access by the Publication and Journals at UBT Knowledge Center. It has been accepted for inclusion in UBT International Conference by an authorized administrator of UBT Knowledge Center. For more information, please contact knowledge.center@ubt-uni.net. 


\title{
Financial Analysis and Techniques to Forecast the possible Bankruptcy of Firms in Terms of Economic Crisis (The Case of Albania)
}

\author{
Antoneta Polo ${ }^{1}$, Vjollca Karapici ${ }^{2}$, Enkela Caca $^{3}$ \\ 1 "Eqrem Cabej" University, Gjirokastra, Albania \\ Email:netapolo@yahoo.com \\ ${ }^{2}$ Tirana University, Tirana, Albania \\ Email:vkarapici@yahoo.com \\ 3 “Eqrem Cabej" University, Gjirokastra, Albania \\ E-mail: ebabaramo@yahoo.com
}

\begin{abstract}
Globalization of markets, continued growth of competition, major technological and innovative changes, has decided Albanian businesses before the big existential challenges. The possibility of bankruptcy knocks at the gate of each of them (especially small and medium business), constituting a problem for the economy of the entire country. Factors that may cause such negative changes are numerous both in number as well as in the consequences with which they are associated. The main purpose of this paper is to make possible the identification of the most important factors that can lead to bankruptcy Albanian businesses and to present models and the main financial analysis techniques may provide a potential bankruptcy. Timely identification of bankruptcy risk through these techniques as well as the elimination of the main causes negative effects on the business, will not only serve as the only business, but all Albanian economy in general.

Keywords: enterprise, bankruptcy, financial analysis, risk, crisis , failure, model.
\end{abstract}

